\title{
The women at the tomb: What are they doing there?
}

\author{
Carolyn Osiek \\ Department of Biblical Literature \\ Catholic Theological Union, Chicago, U.S.A. \\ Visiting Professor: Department of New Testament Studies (Sec A) \\ University of Pretoria
}

\begin{abstract}
This article will explore the role and function of the women in the empty tomb narratives of the Gospel tradition. What purpose do they play in the resurrection kerygma of the early church? Why is the story of their first arrival at the tomb so persistent that it continues into the later apocryphal gospels? The discussion of this question will be in three parts: part one will summarize some of the work on these passages that has been done by scholars using the tools of redaction criticism. Part two will examine some of the surrounding issues from the perspective of social history and social construction of meaning, especially with regard to women's subcultures, roles in burial customs, and public testimony. Part three will apply to these findings a feminist analysis using both a hermeneutic of suspicion and of remembrance.
\end{abstract}

\section{INTRODUCTION}

This article will explore the role and function of the women in the empty tomb narratives of the Gospel tradition. What purpose do they play in the resurrection kerygma of the early church? Why is the story of their first arrival at the tomb so persistent that it continues into the later apocryphal gospels? It has become an exegetical commonplace that women could not be legal witnesses in ancient Judaism, and thus these tomb narratives were not counted among official appearance stories. But if this is so, why were these narratives preserved at all? It is thought by some biblical scholars that the empty tomb stories are secondary to the appearance stories, and even perhaps invented by Mark. If this is so, why women? It would seem to have fit the kerygmatic purposes of early Christian preaching eminently better to have the male disciples come first to the tomb - or, if it be argued that, having fled at the arrest according to the narrative, they would not have known. where the tomb was, then even Joseph of Arimathea, who surely could have come to check on his handiwork! 


\section{REDACTIONAL EMPHASES}

All four Gospels contain accounts of the women as first arrivals to the tomb on Easter morning, but they differ greatly in detail. The common thread to all four accounts is that at least one woman disciple of Jesus, namely Mary Magdalene, came first to the tomb after sabbath, found it empty, and went away again. Also common to the Synoptics is that they (Mary Magdalene and at least one other) received a message from someone(s) to interpret the meaning as the resurrection of Jesus. The number and names of the women are different in each case, as shown below.

\begin{tabular}{|c|c|}
\hline Mark 16:1 & Mary Magdalene, Mary mother of James, Salome \\
\hline Matthew 28:1 - & Mary Magdalene and the other Mary \\
\hline Luke 24:10 & $\begin{array}{l}\text { Mary Magdalene, Joanna, Mary mother of James, } \\
\text { and the others with them. }\end{array}$ \\
\hline John 20:1 & Mary Magdalene \\
\hline
\end{tabular}

In addition:

Gospel of Peter 12:50 - Mary Magdalene and her women friends

Epistula Apostolorum

Ethiopic $9-$

Sarah, Martha, Mary Magdalene

Coptic $9-$

Mary, the daughter of Martha, Mary Magdalene

Only the Epistula Apostolorum does not place the name of Mary Magdalene first.

\subsection{Mark 16:1-8}

One can now speak of a scholarly consensus that the original ending of Mark is at the end of verse 8. The same cannot be said for the questions surrounding the composition of those last eight verses. Some detect the presence of literary sources in the text itself. For others, 16:1-8 is an integral literary unit, composed by Mark. For still others, this literary unity is sufficient indication that Mark not only composed the narrative, but invented ${ }^{1}{ }^{1}$. If one wants to discount all stories of angelophany and search for the historical 'bare bones', the result is, not surprisingly, exactly what was given above as the line common to all four canonical Gospels: some women disciples are first to arrive at the tomb, find it empty, and go away confused.

The women who came at sunrise were the same three who were present and saw (witnessed?) the crucifixion along with other women disciples (15:40-41), and the two Marys saw the burial ( $v 47$ ), even though one of the sons of Mary is omitted alternately 
in 15:47 and 16:1. (To add to the confusion, Codex Vaticanus tries to make her into two people at 15:40: the wife of little James and the mother of Joses. See the conundrum posed by 6:3, where James and Joses are the brothers of Jesus, which would make this Mary the same as the mother of Jesus.) In spite of all this confusion about the male relatives of Mary, there is a continuity in the women's experience. It is explicitly stated that they saw $(\theta \varepsilon \omega \rho o \hat{v} \sigma \alpha \iota)$, even though at a distance $(15: 40)$, the crucifixion of Jesus and where he was buried ( $v$ 47; Salome has disappeared for the burial, but has rejoined the two Marys at the tomb on Sunday morning.) The usual interpretation of their distance from the scene is avoidance of the political danger that closer association would bring (also in Mt 27:55 and Lk 23:49, but contrast Jn 19:25).

The reason given for their return, the unfinished anointing of the body, is highly suspect. It occurs only in Mark and Luke. In Mark, the end of the passion narrative offers no explanation why they could not finish the task on Friday, so that their reason for returning seems artificial. Moreover, reopening the tomb to anoint the body nearly two days later has been seen by most commentators as incredible.' It has been objected that what is envisioned is not complete anointing, but rather a general honorific sprinkling with aromatics around the corpse, as in 2 Chronicles 16:14 or Josephus Antiquities 15.61, prophetically anticipated in Mark 14:8 (Schottroff 1991:181, 200 note 42). But when this anointing was to be done more than thirty-six hours after burial, it still strains credibility.

Those who would see an original, straightforward narrative behind the present text would see it composed of something like verses $1,2,4,8$. Verse 3 , the women's question to each other about how they will gain access to the tomb, is literary embellishment to heighten the sense of amazement in verse 4 when they found the stone already rolled back. The rather subdued angelophany (vv 5-7), if indeed the modest account of a young man in a white robe can even be called that, introduces the kerymatic message of Jesus' resurrection, and is therefore secondary. Verse 7 introduces yet another motif, return to Galilee in keeping with Jesus' own prediction in 14:28, and was perhaps inserted at an even later point.

The complex question of Mark's puzzling ending cannot be discussed here and is not relevant for this investigation, except inasmuch as the silence of the women affects their credibility as witnesses. This will be taken up in part three.

\subsection{Matthew 28:1-10}

Matthew's empty tomb narrative elaborates considerably the simple account of Mark. Two of Mark's three women remain, but they have company: the guards that have been stationed at the tomb (Mt 27:62-66). The women came, not to finish anointing, but 
simply to 'see' $(\theta \varepsilon \omega \rho \eta \hat{\sigma} \sigma \alpha)$ the tomb, to continue the faithful vigil they had been keeping at the time of burial (27:61). And there was plenty to see once they got there: an earthquake, followed by an angel who descended, rolled away the stone, and sat on it (28:2-3). Women and guards were witnesses to the shattering events immediately surrounding the actual resurrection. The contrasting reaction reveals the difference of response. While the guards accepted bribes to falsify what they witnessed (vv 11-15), meanwhile back at the tomb, the women received the angelic message in approximately the same terms as in Mark, including the promise of seeing Jesus himself in Galilee (vv 5-7). As contrasted with Mark, they fled the tomb not in fear and panic, but in fear and great joy to tell the other disciples ( $v 8$ ).

The subsequent appearance of Jesus cutting them off at the pass as they run (vv 910 ) is the most difficult part of the narrative and may be an addition. It adds nothing to the angel's message, but only repeats the message to go to Galilee. Moreover, it seemingly contradicts the angel, who has just told them to deliver the message that 'you will see him in Galilee'. Two verses later, they saw him at Jerusalem - and with nothing new to say. The Synoptic pattern of an angel(s) who sends women to male disciples who, in Matthew and Luke, are then sent to the world, is disrupted. This sudden and strange appearance of Jesus, however, serves to reinforce the essential message: he is risen. Other aspects of its significance include the following: it forges the first link between the empty tomb and appearance traditions; it is the first evidence of the tendency, to be developed in Luke 24 and John 21, to relocate appearances in Jerusalem; and the women's response of worshipful grasping of Jesus' feet (v 9) is evidence of the inevitable tendency to materialize the appearances (Fuller 1971:79). In addition, for Matthew, the first appearance of the risen Jesus was to women disciples.

\subsection{Luke 24:1-11}

Only in Luke are the women disciples mentioned and partially named early on in Jesus' ministry (8:2-3). There with him in Galilee, in addition to the twelve, were women who had been healed and exorcised: Mary Magadalene, Joanna, and Susanna, who is

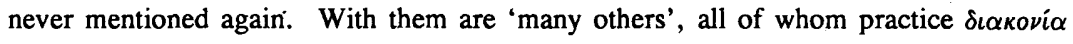
with the twelve. Only here and in Mark 16:9 is Mary Magdalene a former demoniac — and nowhere in the New Testament is she a prostitute! Joanna may have been a woman of some status on the Herodian ladder, and inexplicably, travelled without her husband among a group of whom Herod did not approve ${ }^{2}$. The women reappear in 23: 49, 55 as part of the group of those who had followed Jesus (the language of discipleship) from Galilee to Jerusalem. According to Acts 13:31, they therefore formed part of the group of witnesses to the events of Jesus' death and resurrection. 
Luke is the first evangelist to imply that the male disciples were present at the crucifixion along with the women (23:49), even if at a distance. Only the women, however, witness the burial ( $v 55$ ), so that the textually uncertain visit of Peter to the tomb (24:12) must still presuppose the communication of its location by the women. They will remain nameless until 24:10. Here, in contrast to Mark, they have a reason to return Sunday morning to finish their anointing: the first sundown of sabbath was already beginning while Jesus was being buried ( $v 54$ ), and the women were observant of sabbath regulations ( $v 56$ ).

Though there is no mention in Luke's burial account of the stone being rolled over the tomb entrance, it is presupposed in 24:2, for there, it has already been rolled back. Luke, in common with. Mark, and against Matthew, does not narrate the actual movement of the stone. Only in Luke, the women first saw for themselves that Jesus' body was not there - before they were informed as to the meaning of its absence. Then they are instructed by the two men in dazzling robes, not by means of kerygmatic statements, but two familiar Lukan devices. The first is a rhetorical question: 'Why do you look for the living one among the dead'? ( $v$ 5; compare Acts 1:11). The second is a memory help: 'Remember how he told you about this in Galilee' (vv 6-7), followed by their remembrance of his words, leading to understanding and proclamation. Even though, only in Luke, the women were not given a specific command to tell what they had seen, they did it anyway - but in vain, for they were not believed until Peter verified for himself ( $v v 8-9,11-12)$ and appearances of Jesus later in the day confirmed what had happened.

At 24:10, three of the women are finally named: Mary Magdalene, Joanna (see 8: 2), and Mary mother of James (or wife, if Mk 15:40 is not to be presumed), but there were unnamed others with them. Joanna, the political question mark, has persisted from 8:2 along with Mary Magdalene.

For Luke, the women were certainly counted among the disciples. The angelic message to them at the tomb is not one of direct address, a statement to be repeated to the men. Rather, the message is directed to the women themselves. It is they who are to remember how Jesus, while still in Galilee, predicted his passion and resurrection. Only once in Luke's Gospel, at 9:22, are both passion and resurrection made part of a prediction that is not directed specifically to a closed group, but to the disciples in general. The women disciples, already mentioned in $8: 2-3$, are therefore part of the group of disciples who received the prediction in chapter 9 (Rigato 1993:93-101, 232235), as well as the disciple-witnesses from Galilee in Acts 13:31. In Luke's narrative, they form part of an inclusive pattern of women figures beginning with the prophets 
Mary and Anna in the infancy stories, through, among others, Martha and Mary (10: 38-42), Mary and the women in the upper room at Pentecost (Acts 1:14), and the women prophets of Joel (Acts 2:18).

\subsection{John 20:1-2, 11-18}

With the first two verses of John, we may be once again very close to an original form of the story: a woman disciple goes early Sunday morning to the tomb, finds the stone rolled back, and runs to tell other disciples. The beloved disciple is of course a Johannine insertion, as is Mary's immediate assumption that the body has been stolen. John does not say explicitly that she noticed the body was not there (compare only Luke 24: 3), yet her message presupposes it. Mourning and preparation of a body for burial are social activities for women: the group of women is no doubt the earlier version. It has been reduced by John to Mary Magdalene alone for two reasons: first, the ensuing dialogue between her and Jesus in vv 11-18 was composed as a private encounter, and it is possible that the original narrative continued from verse 1-11 without the intervening episode; second, the focus on her prefigures her centrality in later apocryphal Easter stories as a major authority on communication from the risen Jesus. Some think that the plural 'we' in verse 2 is a remnant of the earlier version and implies other companions, who are not otherwise mentioned for the reasons just given.

In verses 11-18, Mary Magdalene is mourner, lover, and momentarily uncomprehending foil for Jesus' revelation. Only in John is the mourning of the women at the tomb, women's special role at a funeral, made explicit: she stands outside the tomb weeping ( $\mathrm{v} 11)$. But looking in, she 'sees' ( $\theta \varepsilon \omega \rho \varepsilon \hat{i}$; cf. Mt 28:1, etc) two angels in white garments, one at the head and one at the foot of the place where the body of Jesus had been (v 12). Robert H Smith (1983:161) comments as follows:

Ask an audience of ordinary Christians what Old Testament scene comes to mind as they picture two angels in a small dark space stationed one at the head and one at the foot of a shelf or slab, and almost immediately someone will respond, 'The ark of the covenant in the Holy of Holies'. That response is naive, uncomplicated, and correct.

Mary's assumption of body snatchers, in verses $2,13,15$ is portrayed as the raving of a distraught person, for who would steal the body except the disciples, to whom she first reports the loss? Yet it is a strange echo of the false explanation of the empty tomb in Matthew 27:62-66. The motif also prepares for the scene of teasing encounter 
and recognition that is a perennial favorite for those who ponder the Scriptures. Jesus' gentle rebuke about her clinging to him in verse 17 recalls the women's grabbing hold of his feet in Matthew 28:9, the only other canonical account in which the risen Jesus appears to women at the tomb (with perhaps Mk 16:9, where the location of his appearance to Mary Magdalene is not specified). Like the women in the accounts of Mark and Matthew, she is given an explicit commission to tell the male disciples, not this time about a coming appearance in Galilee, but about Jesus' ascension/exaltation. The words of her message to the disciples are the foundation text for later portrayals of Mary Magdalene as privileged recipient of revelation from the risen Jesus and 'apostle of the apostles': 'I have seen the Lord, and this is what he said to me' ( $v$ 18; compare 1 Cor 9:1).

\subsection{Gospel of Peter}

The persistence of the story of women at the tomb is demonstrated by the second-century redactor of this text, who found it necessary to include them, even though they arrive at the tomb after a plethora of witnesses - soldiers, scribes, and elders - have already seen the stone rolled back, two men of transcendent height enter the sepulchre and emerge with Jesus in the middle, with the talking cross behind them, and yet another angelic figure enter the tomb to guard it from the inside and wait for the women (10:38-11:44)!

After all these nocturnal events, Mary Magdalene, a woman disciple ( $\mu \alpha \theta \dot{\eta} \tau \rho \iota \alpha)$ of the Lord, set off for the tomb early in the morning with her women friends (r⿳亠口 $\varsigma$ $\phi i \lambda \alpha \varsigma)$. As in Mark and Luke, they have unfinished business there, but as in John, it is mourning, not anointing. Their reason for not doing it earlier was fear of the Jews. As in Mark, they wondered who would roll back the stone for them, but found the task already done, and a young man who gave them the message of the resurrection. Why they had less fear of the Jews then, especially given the crowd that spent the night at the sepulchre, and why they needed the stone rolled back in order to mourn, are questions not entertained. Also as in Mark, they fled afraid, and it is not said that they told anyone (12:50-13:57). Here, however, they did not have to: half the world already knew! It is interesting to note, however, that the narrative does not provide a line of direct communication about the resurrection events to the male disciples ${ }^{3}$.

Here the story of women at the tomb is still thought important enough to keep in the narrative, even though it seems to serve no purpose, neither first witness nor medium of communication to the other disciples. It can only have been included because it was so much a part of the Easter story that the redactor could not leave it out. 
A look at all five of these narratives leads to the conclusion that behind them lies a core version in which Mary Magdalene is the key figure who arrives first at the tomb, found it empty, and went away confused. If this story is secondary to the appearance narratives and late in coming, then the question must again be asked: What purpose does it serve? Does the proclamation of the resurrection necessitate an empty tomb? It would seem not: As is well known, Paul does not allude to the empty tomb tradition - a fact usually put forth in support of the secondary character of the story - nor does the preaching in Acts, though Acts 2:29-31 and 13:34-37 perhaps presuppose it, both in reinterpretation of Psalm 16:10 (15:10 LXX).

An analysis of the relationship between resurrection beliefs and resuscitated body in the first-century Mediterranean world cannot be done here (see esp Nickelsburg 1972). Most texts are ambiguous, but some, for example, 2 Maccabees 7:11, 23, seem to suggest a close connection, as does one Greco-Roman apotheosis story, that of Hercules by the first-century BCE historian, Diodorus Siculus (Bibliotheca historica 38.35). Hercules mounts the funeral pyre, which is consumed by a bolt of lightning. Those who come afterwards to gather up the remains find no bones, and conclude that Hercules has been translated to the realm of the gods. Paul's analogies to seed sown and astral bodies in 1 Corinthians 15:35-44 are open to a variety of interpretations, but it does seem as if some continuity with the physical is supposed in the pneumatic transformation.

However, a close examination of the resurrection teaching of both Paul and Acts reveals that the core event is the appearances of the risen Christ. The allusions to Psalm 16:10 in Acts 2:29-31 and 13:34-37 are not offered as proofs, but as supporting scriptural arguments. Beyond these passages, the silence of Paul and of Acts about the empty tomb tradition cannot be taken as proof of its secondary nature, for the author of Acts of course knows that tradition. Rather, their silence is indication that the empty tomb tradition is not foundational to the kerygma of the resurrection. For the earliest Christian community, it served 'not as the origin and cause of their Easter faith, but as a vehicle for the proclamation of the Easter faith which they already held as a result of the appearances. It is as such that the Christian historian and the community of faith can accept the report of the empty tomb today' (Fuller 1971:70).

If this is so, the question remains with even greater persistence: What purpose does the tradition of the women at the empty tomb serve? Why was it kept in this form at all? 


\section{SOCIOLOGICAL ISSUES}

In this section, we will consider several aspects of women's cultural behavior in traditional Mediterranean societies and particularly in Judaism, as these considerations bear on the empty tomb narratives: the role played by women in funerals, women's subcultural narrative traditions, and the question of women as witnesses in rabbinic Judaism.

In many traditional societies including those of the eastern Mediterranean, it is women who prepare a body for burial, while men actually convey the body into the tomb. This fits well the Gospel accounts: the women prepare the aromatic spices that were wrapped into the shroud and deposited around it, while Joseph of Arimathea (assisted by Nicodemus in John) makes the public contact with the authorities, places the body in the tomb, and secures it. Both men and women lament, often publicly (e g, $2 \mathrm{Sm} \mathrm{13:}$ 31; 18:33-19:8; Job 1:20; 2:12-13; Ezk 29:30-36; Mk 5:38; Jn 11:33), but it is especially women who carry the tradition with their own particular and culture-specific customs.

The special role of women in mouming is often threatening to male familial and religious authorities, for it is perceived as giving them a power of contact with the dead. Thus woman, who is perceived by male society as having closer connection with birth, is also perceived as having closer contact with death, and that connection with the unclean and the unknown is terrifying and contaminating 4 . Perhaps the suspect motive of unfinished anointing attributed by Mark and Luke to the gospel women for returning to the tomb is farther from the actual situation than that provided by the other accounts. For Matthew, they return simply to see the tomb (28:1); for the Gospel of Peter, to do what women do for their loved ones who die (12:50); and perhaps John is the most forthright and least threatened by women's presence, for Mary Magdalene is simply there, weeping (20:11).

The suggestion has been made that the empty tomb story was preserved (or originated) in women's groups, and finally made its way into the male 'mainstream' canonical tradition. Certainly many traditional cultures segregate male and female company in everyday social interaction, and many eastern Mediterranean cultures yet today belong in this category. One need only be present in a village of Greece, Turkey, or an Arab country for the cycle of work and recreation in an ordinary day to be aware of this. In such a society, women have their own oral traditions and storytelling practices, passed on from generation to generation, that portray life and events from women's point of view (see, e g, Dubisch 1986). It has been frequently noticed that the apocryphal gospels and acts feature stories about women disciples and especially women 
leaders in unprecedented numbers when compared to their canonical counterparts. Indeed, the question is regularly asked whether this is one of the reasons for their noncanonical status (see, eg, Davies 1980; MacDonald 1983; Burrus 1987).

Cycles of stories that originate in women's storytelling circles presumably tell women's side of an event. This is precisely what the empty tomb stories do, with appearances of the risen Jesus to women added in Matthew's and John's versions. A different light is shed on the original function of the empty tomb narrative if it can be seen as a 'private' version from the world of women, over against the 'public' version of appearances to the male disciples, like the very early list in 1 Corinthians 15:5-7. This list includes no appearances to women. Could it be that the reason for Paul's silence about appearances to women, let alone the empty tomb, is not because the story is secondary, but because it has not yet made its way from the 'private' female kerygmatic tradition to the 'public' male kerygmatic tradition?

This brings us to the question of the ability or inability of women to be public witnesses according to Jewish law. It has become an unexamined scholarly commonplace in Christian exegesis that women's incapacity to serve as public witnesses is a major reason for the exclusion of appearances of the risen Jesus to women in the official testimonies of Acts and 1 Corinthians 15. This judgment relies heavily on a statement by Josephus (Antiquities 4.219) to the effect that Moses' legislation included a prohibition of women serving as legal witnesses because of their 'lightness and presumption' ( $\delta \iota \grave{\alpha}$

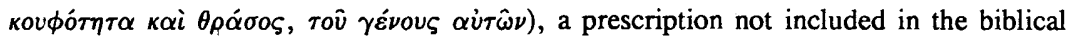
law codes, but quite congruous with Josephus' valuation of women.

In fact, the inability of a woman to serve as witness in ancient Judaism is not so clear in Mishnaic law. Use of these sources to shed light on first-century Judaism must always be done with caution, since the compilations were done several centuries later, but these are the texts that have traditionally been drawn on by scholars to justify the women's exclusion as witnesses to the resurrection and Paul's silence about the role of the women in 1 Corinthians 15:3-8. Several points may be relevant.

First, women are disqualified from serving as witnesses in a case that necessitates bringing an accusation against another. This is an exemption, not an exclusion, since those not exempted are required to bear witness when necessary. Women are therefore exempted from being compelled to initiate public testimony of a crime committed. This situation does not apply to our case.

Second, a woman can testify in matters of credibility, especially on questions that pertain particularly to women (e g, virginity — including her own); when she was the only one present; in order to free herself or another from a legal obligation (e $\mathrm{g}$, the death of a husband); and in certain cases when men are not present or it would not be 
appropriate for them to be there. In business matters, a woman can take an oath of deposit and swear to her own honesty. Women's testimony is valued and drawn upon in the sphere of private affairs, but not in public, reaffirming a traditional distinction often made by modern scholars. That is, in domestic, family, and private law (including business contracts), women function as legal persons. But the general reluctance in ancient Mediterranean society to see women as public spokespersons or officeholders applies here as well (cf Meiselman 1978:73-80; Wegner 1988:120-126, 188-1895).

But how does all of this apply to the Gospel empty tomb narratives? In all four Gospels, Mary Magdalene and others are credibility witnesses, a credibility that is patently rejected by the male disciples in Luke 24:11. In Mark, Matthew, and Luke, the women were the continuous witnesses to Jesus' death, burial, and empty tomb. In Matthew and John, as well as Mark 16:9, they were the first to have an appearance of the risen Christ. In John 20:18, Mary Magdalene gives testimony in formulaic language: 'I have seen the Lord, and these are the things he said to me' (cf 1 Cor 9:1). Credibility is exactly what is at stake in their witness, a witness that is variously received by the male disciples until it is corroborated by their own experience. The silence of later preaching about the women's witness is not so surprising in the public speeches of Acts, located for the most part in public situations with unbelievers. Any respectable ancient eastern Mediterranean male would try to shield the women of his group from such public scrutiny and the risk of scorn. Paul's silence about the women in his enumeration of appearances in 1 Corinthians 15:5-7, however, in the in-house environment of a group of Christian house churches, is more difficult to explain and will be discussed further below 6 .

\section{A FEMINIST ANALYSIS}

We turn now to an analysis of our findings from the perspective of feminist hermeneutics. First, a hermeneutic of suspicion presupposes that a critical approach to the narratives is necessary in order to expose the androcentric bias operative in the selective transmission of the tradition.

Mark's silencing of the women in 16:8 is subject to many diverse interpretations. One effect, however, is to eliminate the women as witnesses and discredit their reliability: one way of reading the verse is that they did just the opposite of what they were commanded, creating the ultimate failure of discipleship and apostleship in Mark. While those earlier in the Gospel who were told not to proclaim what they had seen did so anyway $(1: 44-45 ; 7: 36)$, now when proclamation is finally mandated, the women fail to do it. 
What is far more serious, the denial of any historicity to the empty tomb stories completely dismisses the women's role in the original resurrection experience, for without the empty tomb, they play no part. Only the second ending of Mark, recognized by scholarly consensus as secondary and as late as the second century, does not explicitly locate the appearance of the risen Jesus to Mary Magdalene at the tomb (Mark 16:9).

Why do Paul and Acts pass over the empty tomb narratives, and therefore the role of the women, in complete silence? One of two alternative answers is usually given. First, the whole motif of the empty tomb is secondary and late, and Paul does not mention it because he does not know of it. Since it is not an apologetic story and offers no new proof on its own, it makes no difference whether there are men or women at the tomb. This reason, of course, does not explain Luke's silence in Acts, for Luke does surely know the story and has already told it. Though the empty tomb seems presupposed twice in Acts $(2: 25-31 ; 13: 34-37)$, it is never made an explicit part of the resurrection witness. The second reason offered, therefore, is that resurrection faith from the very beginning was based not on the empty tomb but on testimony to the appearances of the risen Christ, and it is to this that the earliest kerygma appealed. With this explanation the role of the empty tomb stories is moot; the empty tomb can stay, but it is simply not necessary. It enhances the meaning of the resurrection, but does not add further proof, for the simple reason that the explanation, without supernatural intervention, could just as well be that the body was stolen.

Still a third explanation offered is that Paul represents the combination of Luke's Jewish-Christian Jerusalem tradition with Paul's Hellenistic tradition that does not include the empty tomb, at the expense of others like the Johannine (cf Bovon 1984: 52). In this case, Mark and Matthew would represent a Galilean tradition that features the women who came from Galilee. Again, this is a possible explanation for Paul, but does not explain the silence regarding the empty tomb in the preaching of Acts. A fourth explanation, suggested above in part two, is that the empty tomb stories originated in women's circles, and have not yet made their way into the male kerygmatic tradition at the time of the writing of 1 Corinthians. Again, this does not explain the absence of the empty tomb motif in Acts.

However possible or probable some of the above explanations may be, none of them take into account the effect of the elimination of the women's witness. Given the assumed androcentric bias of the accounts (which could have operated almost unconsciously and need not presume active misogyny), it is possible that the empty tomb stories are very old, but are passed over in silence by Paul and Acts precisely because they involve the testimony of women. That is, they are not considered as proof of the 
resurrection, not because faith is based on appearances, but rather the other way around: faith is based on appearances, not the empty tomb, because the empty tomb necessitates reliance on the credibility of women, whereas the abundant male experiences of appearances do not. It is significant for this argument that the appearances to women (Mt 28:9-10; Jn 20:11-18) do not feature in 1 Corinthians 15:5-7 either. Once the empty tomb is eliminated, it is not difficult to eliminate also the appearances to the women, which are tied to the tomb narratives and setting except in Mark 16:9.

Yet the empty tomb and the appearances to the women could not be completely eliminated, despite the evidence from Paul and Acts that this was tried. The authority of Mary Magdalene's testimony could not be so easily repressed in the memory of the early church, even if it did not develop until much later in orthodox circles. In other traditions, the tension between the developing authority of the Twelve with Peter as their spokesman and that of Mary Magdalene as primary witness can be seen in such documents as Gospel of Thomas (114) and the fragmentary Gospel of Mary. In the former, a Coptic collection of Jesus' sayings from the gnostic Nag Hammadi library, Peter tries to dismiss Mary from the disciples as unworthy of eternal life. Jesus rebukes him by assuring that by becoming spiritual, that is, male, Mary too - and every female who makes herself male - will enter the kingdom of heaven. Whatever the symbolic meanings of female and male in this account, it is clear that the authority of Peter and that of Mary face off against each other, and Mary is included rather than rejected - but only at the expense of what modern interpreters would consider her integral feminine self.

The Gospel of Mary, preserved partially in Coptic from Nag Hammadi and partially in Greek from the early third century, includes Mary's communication to the disciples of the special revelation given her by the risen Christ, a frequent motif in gnostic gospels. But unlike most, here her testimony is followed by Peter's refusal to accept it, since he refuses to believe that the Savior spoke to Mary rather than to him and the male disciples. He asks rather petulantly if Jesus preferred her to them. Peter is rebuked by Levi, who declares that the Savior knew her well and loved her more than them (Gospel of Mary 2-31). This time Mary is fully vindicated. These glimpses from the early church of traditions in competition, probably based on John 20:11-18, show how strong was the enduring memory of Mary Magdalene, and how much of a threat her memory was to those who would reject her authority (see O'Collins \& Kendall 1987:631-646; Hengel 1963:243-256).

The stories of the events at the tomb from the experience and the memory of women erupt into the 'public' world and the public testimony of the written Gospel accounts, prompting the celebration of a hermeneutic of remembrance. The empty 
tomb narratives mean that the least significant members of the community were entrusted with the first Easter encounter and the first mandate to proclaim it, reaffirming once more that the last shall be first and the poor shall be blessed. The women disciples who followed Jesus from Galilee to Jerusalem, even to his death on a cross, faithfully performed their diakonia of service, witness, and representation (Mk 15:40-41; Mt 27:55-56; Lk 8:1-3; 24:10). The empty tomb narrative is an epiphany story. It is the women's story, and they are the protagonists, for the story is about how they are changed, just as surely as Acts 9:1-19 is about how Paul is changed (cf Schottroff 1991:183).

The purpose of the empty tomb stories has less to do with proof than with meaning. The empty tomb indicates not the presence of Jesus (except in the two instances of appearances), but his absence: ' $\mathrm{He}$ is risen, he is not here'. Yet if the entire story is secondary, it surely would have disappeared, or at least the women would have vanished from it, for they and the story came to serve no kerygmatic purpose in the canonical tradition. But they remained because the memory of their role was so persistent that it could not be removed. Its very persistence must indicate that something actually happened that Sunday morning at the tomb.

* This article was published in Ex Auditu 9 (1993), 97-107, by Pickwick Publishers, 4137 Timberlane Drive, Allison Park, PA 15101-2932, USA. HTS is granted permission to reprint this article.

\section{End Notes}

1 Examples of these three positions, in the same order, are: Fuller (1971:50-70); Neirynck (1980:56-88); Collins (1992:119-48). A summary of opinions on the historicity of the empty tomb to 1970 can be found in Bode (1970:151-59). See also Perkins (1984).

2 Compelling portraits of Mary Magdalene as one healed of mental illness, and of Joanna as a well-to-do and independent lady are given by Moltmann-Wendel (1982:61-90, 131-44).

3 While the Gospel of Peter contains invaluable information about the development of Gospel traditions, I am not persuaded by the argument that its earliest core predates and influenced the canonical tradition (cf Crossan 1988).

4 The tradition of women's lament as a form of alternate social power still survives in rural Greece, but is rapidly disappearing (see esp Holst-Warhaft 1992; Caraveli 1986:169-94).

5 Wegner's conclusion is that in matters of sexuality and reproduction, women are treated legally as men's property, while in all other aspects, they are legal persons in their own right. 
6 At issue here is the symbolic location of the house church: a public gathering, as suggested by Paul's selection of the word $\dot{\varepsilon} \kappa \kappa \lambda \eta \sigma i \alpha$, or a private, semi-household gathering, as suggested by its location in a private house (see Barton 1986:225-246).

\section{Works Consulted}

Abu-Lughod, L 1986. Veiled Sentiments: Honor and Poetry in a Bedouin Society. Berkeley: University of California Press.

Bode, E L 1970. The First Easter Morning: The Gospel Accounts of the Women's Visit to the Tomb of Jesus, 151-159. Rome: Pontifical Biblical Institute. (Analecta Biblica 45.)

Bovon, F 1984. Le Privilège Pascal de Marie-Madeleine. NTS 30, 50-62.

Barton, S C 1986. Paul's Sense of Place: An Anthropological Approach to Community Formation in Corinth. NTS 32, 225-46.

Burrus, V 1987. Chastity as Autonomy: Women in the Stories of the Apocryphal Acts. Lewiston/Queenston: Edwin Mellen. (Studies in Women and Religion 23.)

Caraveli, A 1986. The Bitter Wounding: The Lament as Social Protest in Rural Greece, in Dubisch, J (ed), Gender and Power in Rural Greece, 169-94. Princeton: Princeton University Press.

Collins, A Y 1992. The Empty Tomb and Resurrection according to Mark, in The Beginning of the Gospel: Probings of Mark in Context, 119-48. Minneapolis: Fortress.

Crossan, J D 1988. The Cross That Spoke: The Origins of the Passion Narrative. San Francisco: Harper and Row.

D'Angelo, M R 1990. Women in Luke-Acts: A Redactional View. JBL 109/3, 44161.

Davies, S L 1980. The Revolt of the Widows: The Social World of the Apocryphal Acts. Carbondale/Edwardsville, IL: Southern Illinois University Press.

Fiorenza, E S 1986. A Feminist Critical Interpretation for Liberation: Martha and Mary: Luke 10:38-42. Religion and Intellectual Life 3, 21-35.

Fuller, R H 1971. The Formation of the Resurrection Narratives. New York: Macmillan.

Hengel, M 1963. Maria Magdalena und die Frauen als Zeugen, in Abraham unser Vater: Festschrift für Otto Michel zum 60. Geburtstag, 243-56. Leiden: Brill.

Holst-Warhaft, G. Dangerous Voices: Women's Laments and Greek Literature. London/New York: Routledge.

Jervell, J 1984. The Daughters of Abraham: Women in Acts, in The Unknown Paul: Essays on Luke-Acts and Early Christian History, 146-57. Minneapolis: Augsburg. 
MacDonald, D R 1983. The Legend and the Apostle: The Battle for Paul in Story and Canon. Philadelphia: Westminster.

Meiselman, M 1978. Jewish Woman in Jewish Law. New York: KTAV Press.

Moltmann-Wendel, E 1982. The Women around Jesus. New York: Crossroad.

Neirynck, F 1980. Marc 16, 1-8 tradition et rédaction. Ephemerides Theologicae Lovanienses 56, 56-88.

Nickelsburg, G W E 1972. Resurrection, Immortality, and Eternal Life in Intertestamental Judaism. Cambridge, MA: Harvard University Press.

O’Collins, G \& Kendall, D 1987. Mary Magdalene as Major Witness to Jesus' Resurrection. Theological Studies 48, 631-46.

Perkins, P 1984. Resurrection: New Testament Witness and Contemporary Reflection. Garden City: Doubleday.

Rigato, M-L 1993. 'Remember ... Then They Remembered': Luke 24:6-8, in O'Collins, G \& Marconi, G (eds), Luke and Acts, 93-101, 232-235. New York/Mahwah, NJ: Paulist Press.

Schaberg, J 1992. Luke, in Newsom, C A \& Ringe, S H (eds), The Women's Bible Commentary, 275-292 . Louisville, KY: Westminster/John Knox.

Schottroff, L 1991. Mary Magdalene and the Women at Jesus' Tomb, in Let the Oppressed Go Free: Feminist Perspectives on the New Testament, 168-203. Loisville: Westminster/John Knox.

Smith, R H 1983. Easter Gospels: The Resurrection of Jesus According to the Four Evangelists. Minneapolis: Augsburg.

Wegner, J R 1988. Chattel or Person? The Status of Women in the Mishnah. New York: Oxford University Press. 